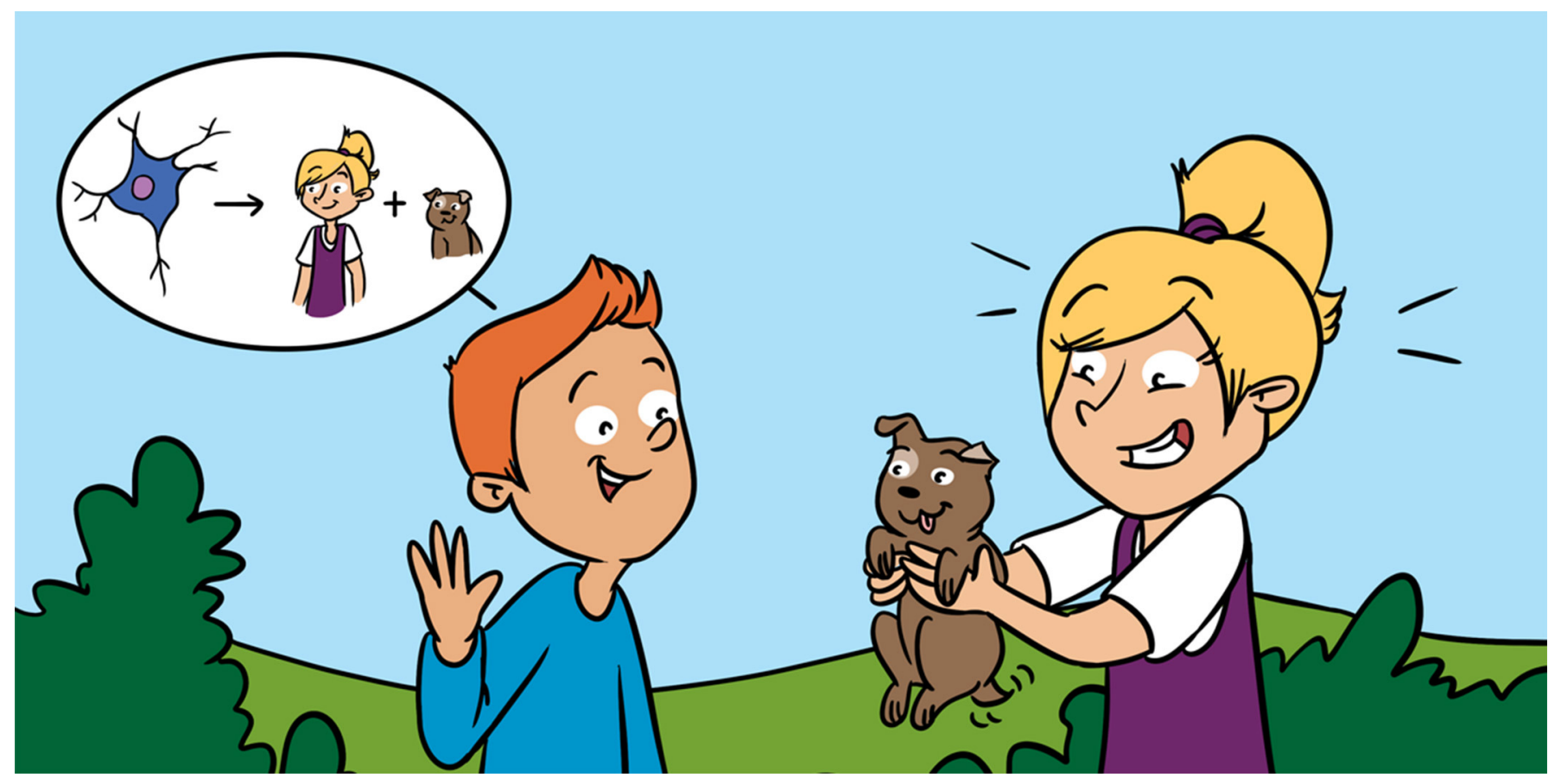

\title{
HOW DOES THE BRAIN LEARN TO LINK THINGS TOGETHER?
}

\section{Leila Reddy ${ }^{1,2 *}$, Matthew W. Self ${ }^{3}$ and Pieter R. Roelfsema ${ }^{3,4,5}$}

${ }^{1}$ Centre de Recherche Cerveau et Cognition, Université de Toulouse, Université Paul Sabatier, Toulouse, France

${ }^{2}$ CNRS, UMR 5549, Faculté de Médecine de Purpan, Toulouse, France

${ }^{3}$ Department of Vision and Cognition, Netherlands Institute for Neuroscience (KNAW), Amsterdam, Netherlands

${ }^{4}$ Department of Integrative Neurophysiology, Centre for Neurogenomics and Cognitive Research, Vrije Universiteit, Amsterdam, Netherlands

${ }^{5}$ Psychiatry Department, Academic Medical Center, Amsterdam, Netherlands

\section{YOUNG REVIEWERS:}

MT. ROSE

ELEMENTARY

AGES: 13-14
We constantly link different things together: new kids and their names, faces and voices, green eggs and ham. How does our brain achieve this? The purpose of this study was to understand how the brain creates these links. What happens in brain cells when we learn that two things (e.g., a new kid and her name) go together? In an experiment we asked human participants to learn to link different items together. As the participants learned these links, we found that nerve cells in their brains also linked these items together. These nerve cells were found in a region of the brain called the hippocampus. In this article, we will first explain how it is possible to listen to nerve cells in the human brain. Then we will show some examples of the responses of these nerve cells, and finally, how the cells can link different items together. 


\section{HOW DOES THE BRAIN LINK RELATED OBJECTS?}

The purpose of our study was to understand how the brain links different things together. Imagine your friend gets a new dog. Your brain quickly learns this new link between your friend and the dog. Every time you see this dog, you know it belongs to your friend. We wanted to understand how nerve cells in the brain store these links. As we explain below, when you look at different things, some nerve cells in your brain get powered on. Our hypothesis was that, when you learn the link between your friend and his dog, the same nerve cells would get powered on for both your friend and his dog.

\section{HOW CAN WE LISTEN TO NERVE CELLS?}

Nerve cells are special cells in our brains. There are billions of nerve cells in the brain, and they are responsible for all that we think and do. For example, every time you look at something, a bunch of nerve cells in your brain get powered on and pass on messages to other nerve cells about what you are looking at. So, if we want to know if a nerve cell has been powered on by something (e.g., your friend or his dog), we need to be able to listen to these messages. When nerve cells get powered on, they send their messages to one another in the form of small electric currents. To listen to nerve cells, we need to be able to measure these small electric currents. Electric currents can be measured with tiny wires that are called electrodes. Each nerve cell has a very small voice (the electric current is very small). So, to listen to individual nerve cells, we need to get our electrodes really close to them. This means that the electrodes need to be inserted into the brain, up close to the nerve cells that we want to listen to.

\section{HOW CAN WE INSERT ELECTRODES INTO THE HUMAN BRAIN?}

Inserting electrodes into the human brain is unusual. However, in some situations, doctors have to insert electrodes into the brains of their patients to listen to the electrical activity in their brains. For example, in patients with epilepsy, groups of nerve cells start talking to each other in abnormal ways, and the messages they send to each other get all mixed up for a few minutes. In many cases the patients lose consciousness and fall on the ground. In this condition, doctors often need to find out where this abnormal chatter is coming from. In extreme cases of epilepsy, doctors insert electrodes into the patient's brain to listen to this chatter. One brain area that is almost always investigated with electrodes is the hippocampus. The hippocampus is a structure deep in the brain that looks a little like a seahorse, and that plays an important role in learning and memory. 


\section{FIRING A SPIKE}

Nerve cells in the brain are said to "fire a spike" when they send information to other nerve cells. The "spikes" are tiny

electric currents.

HERTZ

A unit of measure for the frequency of an event. Hertz measures how often an event occurs in $1 \mathrm{~s}$. In this article we measure how many spikes a nerve cell fires in $1 \mathrm{~s}$, and express the firing response in units of Hertz.
Most patients who have electrodes inserted into their brains do not mind also performing a few experiments that are not for curing their disease, but that can help scientists like us understand how the brain works. In a typical experiment, patients sit in their hospital beds, or on a chair in their hospital rooms. The electrodes in their brains are connected to computers that record the electrical activity of their nerve cells.

\section{NERVE CELLS IN THE BRAIN GET POWERED ON WHEN WE LOOK AT THINGS}

Before we show you what nerve cells do when you learn to link items together, it is important to first understand what nerve cells do when you look at something. As we said above, different nerve cells get powered on. How do scientists understand the response of these nerve cells? Very simply, we just count the number of times the nerve cells turn on. This response of nerve cells is also known as firing a spike, and this response is measured in units of Hertz.

In early experiments we showed patients pictures on a computer screen. We were interested in finding out whether the nerve cells responded to one or more of the pictures that we showed the patient. Eight patients participated in our first experiment [2]. We showed the patients about 100 different pictures of famous people, like the actresses Jennifer Aniston or Halle Berry, famous places like the Sydney Opera House, or the Leaning Tower of Pisa, as well as photographs of non-famous people and places, animals, vehicles, and so on.

For each picture, we counted the number of times the nerve cell fired a spike each time that picture was shown. A nerve cell that does not respond to a given picture will fire the same number of times before the picture is shown and during the time when the picture is shown. On the other hand, if a nerve cell gets powered on in response to a given picture, it will fire a lot of spikes when the patient sees the picture (Figure 1). In the example shown in Figure 1, one particular nerve cell in a given patient fired a lot of spikes in response to a photograph of the actress Jennifer Aniston, and to a photograph of an elephant, but this same nerve cell did not respond to the picture of the basketball player.

We next asked if a nerve cell that responds to a given picture would also respond to related pictures. For example, would a nerve cell that responds to Jennifer Aniston also respond to different pictures of the actress? What about her name written down? To answer this question, we showed the patient many pictures again, but this time we included seven new pictures of Jennifer Aniston. The pictures were quite different from each other-for example, some pictures showed her from the front, in some she was smiling, she was standing in 
Figure 1

\section{(A) The}

hippocampus is a structure located deep in the brain. (B) Some nerve cells respond to pictures. Here you see the response of one nerve cell to three pictures. The blue dotted lines show you the time during which the image was presented. Before and after this period, no picture was shown. If a nerve cell responds to a particular picture, it increases its response when this picture is shown compared with the period before the picture is shown. For the first two pictures, you can see that the nerve cell sharply increased its response, but it did not respond to the third picture.
A

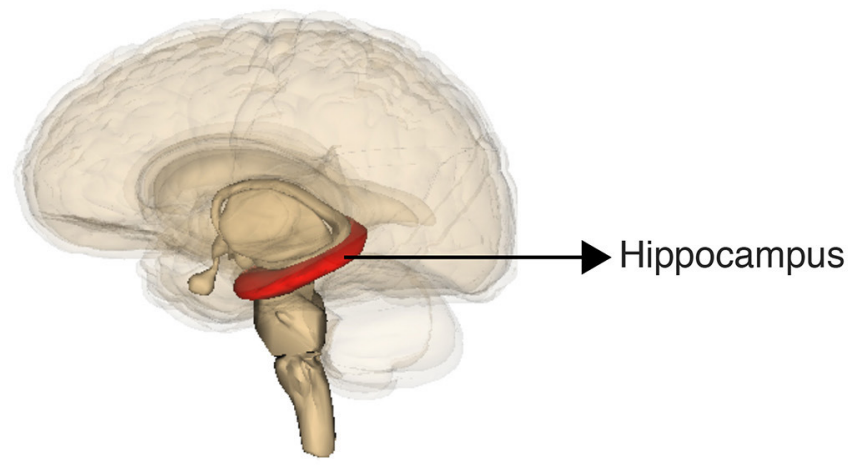

B
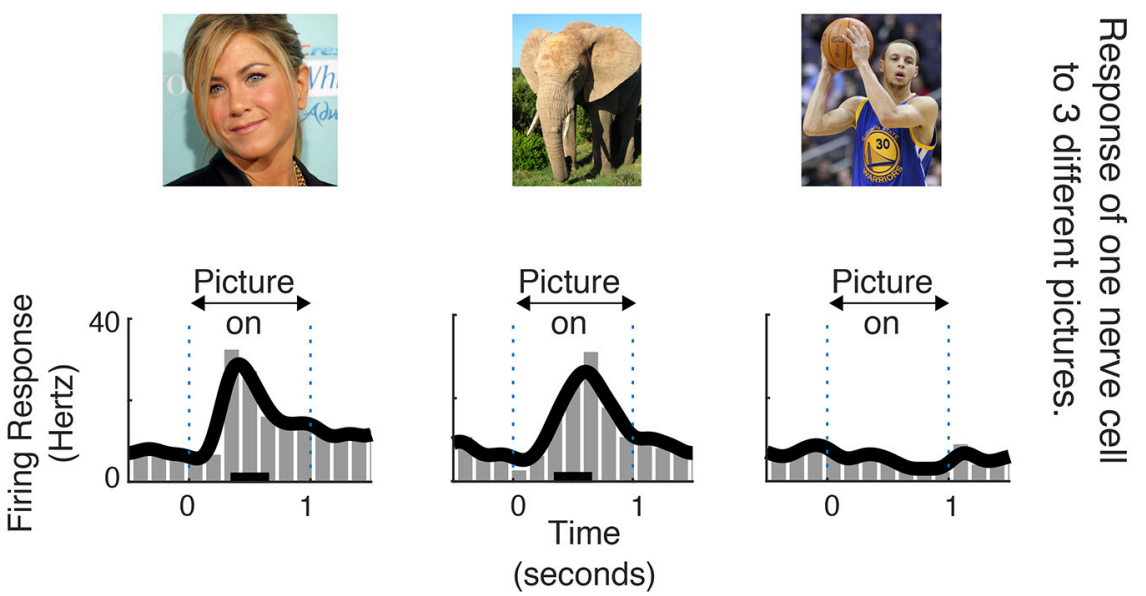

Figure 1

different surroundings in all the pictures, etc. However, we found that the same nerve cell fired to all the different pictures of the actress, and not very much to pictures without Jennifer Aniston. Another nerve cell in another patient responded to the actress Halle Berry (Figure 2). In other words, these nerve cells linked together different pictures, despite the differences between the pictures! The two nerve cells in Figure 2 are from two different patients, and we found similar cells in all other patients too.

\section{DO HUMAN HIPPOCAMPAL NERVE CELLS LINK RELATED OBJECTS?}

These examples show that related pictures were linked together by these nerve cells. This finding led us to our hypothesis - that when you learn to link two items together (e.g., your friend and his dog), the same nerve cells get powered on for both items [3].

To test this hypothesis, we ran another experiment in which a new group of eight patients had to learn that two objects were linked together [4]. We tested whether nerve cells in the hippocampus would also link these two objects together. 
Figure 2

Two nerve cells in two different patients that responded to related images. The first row shows the response of a nerve cell in the hippocampus that responded to seven different pictures of the actress Jennifer Aniston. This nerve cell did not respond to pictures of a famous basketball player, as you can see in Figure 1B. The height of the bars tells you how strong the response of the nerve cell was-the higher the bar, the stronger the response. The second row shows the response of another hippocampal nerve cell, in another patient, that responded to different views of the actress Halle Berry. This nerve cell responded to photographs, a line drawing of the actress, Halle Berry dressed up as Catwoman, and also to her name. In both examples, the nerve cells seem to be linking the different pictures together.

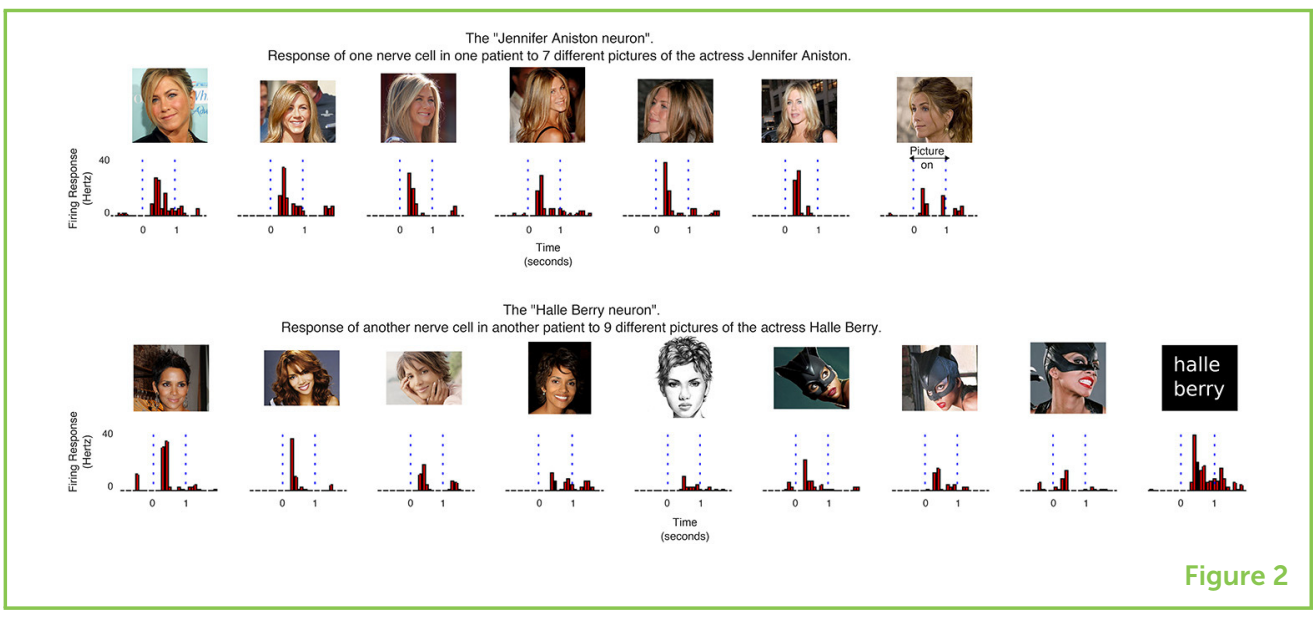

In the example in Figure 3, one patient learned that the red car was linked to the actor Brad Pitt. We then asked whether a nerve cell that responded to Brad Pitt would also respond to the picture of the red car. Would the nerve cell learn to link the red car with Brad Pitt? We counted the number of times the nerve cell fired in response to the red car before the patients learned the link and compared this with the number of times the nerve cell fired to the red car after the patients learned the link. If the nerve cell learned the link, then it should fire more often to the red car after the patients started linking the two items together.

The response of one nerve cell before and after learning is shown in Figure 3. As you can see, before the patient learned the link, the nerve cell did not respond to the red car. However, after the patient learned to link the picture of the red car with the picture of Brad Pitt, the nerve cells that at first only responded to Brad Pitt also started responding to the picture of the red car. In other words, as the patient linked these two pictures together, the nerve cell also linked them together. Again, the nerve cell shown in Figure 3 is an example from one patient. We found similar results in 36 other nerve cells in this group of eight patients.

\section{CONCLUSIONS}

We discovered that nerve cells in the hippocampus link together items that occur together. In other words, as we go about our daily lives constantly linking together all sorts of new items (like your friend and her name), nerve cells in the hippocampus are busily engaged in creating these new associations in our brains.

How long do hippocampal nerve cells store these links? Suppose you change schools and no longer link the old, familiar faces, and names. How often do you need to bring those faces and names to mind, for those links to remain? Many studies now show that, after some time, the hippocampus ships old information to other brain regions 
Figure 3

(A) Our patients were asked to make links between different pictures, for example, the image of the red car with the image of the actor Brad Pitt. (B) The response of one example nerve cell in the hippocampus is shown. On the left, before the patient learned the link between the two pictures, the nerve cell only increased its firing activity in response to the picture of Brad Pitt. On the right, after the patient learned to link the red car with Brad Pitt, the nerve cell increased its firing activity in response to the red car and the actor. In other words, the nerve cell responded to both of the objects that had been linked together.
A Examples of pictures linked by subjects

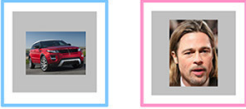

B Response of a nerve cell before learning the link

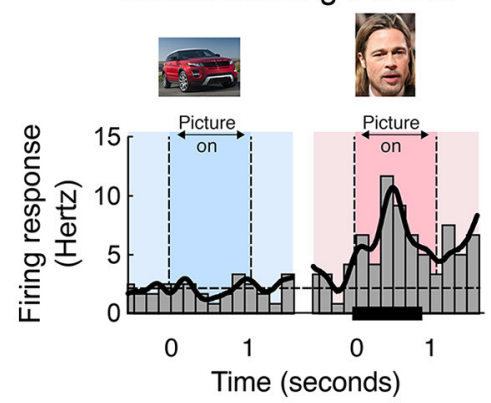

Response of the same nerve cell after learning the link

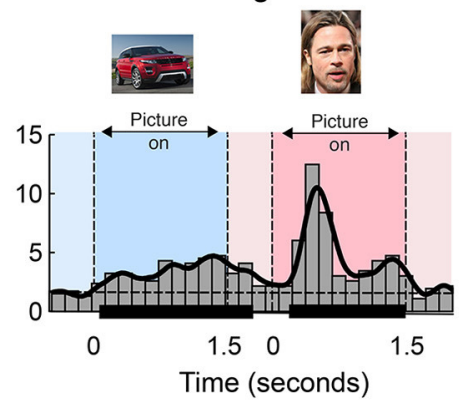

Figure 3 for long-term storage, but it is not clear how much time passes before this occurs. These critical questions of how memories arise, where and how they are stored, and what factors determine whether they are preserved are all open ones. Further research will continue to show how our brains make memories.

\section{REFERENCES}

1. Rogers, S. and Buzsáki, G. 2019. What Is Epilepsy and How Can You Help Someone With It? Front. Young Minds. 7:52. doi: 10.3389/frym.2019.00052

2. Quiroga, R. Q., Reddy, L., Kreiman, G., Koch, C., and Fried, I. 2005. Invariant visual representation by single neurons in the human brain. Nature 435:1102-7. doi: 10.1038/nature03687

3. Reddy, L., and Thorpe, S. J. 2014. Concept cells through associative learning of high-level representations. Neuron 84:248-51.

doi: 10.1016/j.neuron.2014.10.004

4. Reddy, L., Poncet, M., Self, M. W., Peters, J. C., Douw, L., van Dellen, E., et al. 2015. Learning of anticipatory responses in single neurons of the human medial temporal lobe. Nat. Commun. 6:8556. doi: 10.1038/ncomms9556

SUBMITTED: 17 January 2019; ACCEPTED: 28 November 2019; PUBLISHED ONLINE: 09 January 2020.

EDITED BY: Gideon Paul Caplovitz, University of Nevada, Reno, United States

CITATION: Reddy L, Self MW and Roelfsema PR (2020) How Does the Brain Learn to Link Things Together? Front. Young Minds 7:144. doi: 10.3389/frym.2019.00144

CONFLICT OF INTEREST: The authors declare that the research was conducted in the absence of any commercial or financial relationships that could be construed as a potential conflict of interest. 


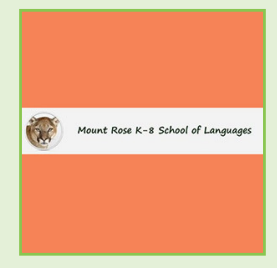

COPYRIGHT @ 2020 Reddy, Self and Roelfsema. This is an open-access article distributed under the terms of the Creative Commons Attribution License (CC BY). The use, distribution or reproduction in other forums is permitted, provided the original author(s) and the copyright owner(s) are credited and that the original publication in this journal is cited, in accordance with accepted academic practice. No use, distribution or reproduction is permitted which does not comply with these terms.

\section{YOUNG REVIEWERS}

\section{MT. ROSE ELEMENTARY, AGES: 13-14}

We are Mt. Rose! We are a group of eighth grade students at an honors academy attending Mt. Rose Elementary. Our free time is spent gaming, skating, drawing, boxing, eating, and sleeping. We work hard and are not afraid of a challenge, both inside the classroom and out. We are looking forward to next year as we begin our High School career.

\section{AUTHORS}
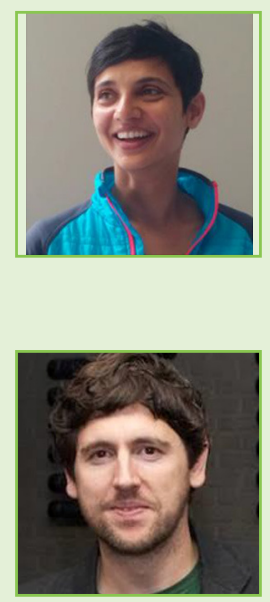

\section{LEILA REDDY}

Leila Reddy grew up in India, studied in the US, and is now a scientist in France. She obtained her Ph.D. in Neuroscience from Caltech. Before that, she studied Chemistry and Math. She has two young kids and thinks it might be fun to read scientific articles for kids with them when they are older. She likes reading, both books for grown-ups and also books for kids. *leila.reddy@acnrs.fr

\section{MATTHEW W. SELF}

Matt Self comes from Ipswich in the UK and studied Neuroscience in Cambridge and London before moving to Amsterdam, where he still lives. He has two children, who are still too young to read Frontiers for Young Minds, but his 4-years old does know a lot about dinosaurs. As well as being a scientist, he also loves music and plays the mandolin.

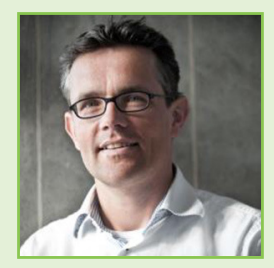

\section{PIETER R. ROELFSEMA}

Pieter Roelfsema has lived in the Netherlands for most of his life. He worked in Germany for a few years. He studied medicine because he wanted to heal patients. But he was later attracted to work as a scientist, because he wants to know how the brain works. He has three children who are 14, 18, and 21 years old. He likes to see his children play field hockey, and to ride his bike to work. 